\title{
CLOSURE OF SERBIAN ELEMENTARY SCHOOL IN SHKODRA IN 1934
}

ABSTRACT. After signing the treaties of Tirana, Albania became the representative of Italy for the Balkans. The activities directed toward the Kingdom of Yugoslavia were determined by Yugoslav and Italian relations, which were rather tense at that period. General negation of Yugoslav presence in Albania was evident in the area of education, and as a result, Serbian schools were closed in territories predominantly inhabited with Serbian people, under the pretext of carrying out reforms. The example of the Serbian elementary school in Shkodra best reflects the effects of Albanian education policy regarding ethnic minorities.

Archives of Yugoslavia, department of the Ministry of Education, contains the file (pages of documents) related to this school. This paper is based on the mentioned file, as well as available general literature on Yugoslav Albanian relations.

KeYwords: Serbian elementary school in Shkodra, Albania, Kingdom of Yugoslavia, education policy.

This paper was submitted on September $12^{\text {th }}, 2021$ and accepted for publication at the meeting of the Editorial Board held on November $16^{\text {th }}, 2011$. 
In the 1930s, the relations of Yugoslavia and Albania deteriorated after Albania was proclaimed kingdom, and Ahmed Zogu became King of Albanians (King Zogu I). Such a title put in a claim to Yugoslav territories inhabited by Albanians. The Yugoslav side observed the course of events calmly, considering this as the logical sequence of events after signing the treaties of Tirana. These treaties, signed in 1926 and 1927, resulted in Italian protectorate over Albania, but also a stronger pressure on Yugoslav Kingdom (Аврамовски, 1986, p. 2528; Милак, 1987, р. 41-42; Павловић, 2001; Krizman, 1975, p. 51; Велојић, 2016, p. 145-147). Albanian external politics clearly showed that their attitude towards an eastern neighbour would be determined by the relations of Yugoslavia and Italy. During the second Balkan Conference in Constantinople 1931, Albanian delegation submitted a memorandum on unfavourable status of Albanian national minority on the territory of Yugoslavia. In response to this memorandum, the Yugoslav delegation stated that Balkan Pact should prevent the influence of big countries on certain states, which openly criticised Italian influence in Albania (Аврамовски, 1986, p. 51). The Albanian side itself, however, was not delighted with those pacts, and they did not renew them upon their termination. In 1930, there were several newspaper articles in Albanian press, fiercely condemning Italian allies, which were presumed to have been instigated by the official circles. ${ }^{2}$ After failed assassination of King Zogu in Vienna in $1931,{ }^{3}$ the relations with Yugoslavia were further undermined, since its government was held responsible for it. ${ }^{4}$

Impaired Yugoslav-Albanian relations affected both position and status of the ethnic minorities, especially Serbian minority on the territory of Albania. Albanization of Serbs was done systematically, mostly through education policy, which called for closure of schools in foreign languages. Since a lot of Serbian population lived in Shkodra and the vicinity, there was a Serbian elementary school in the city, founded in 1828 (more detailed: Протић, 1914). The school was under jurisdiction of the local clerical-school community, holding tight connections with the eparchy of Prizren. The closest ties of

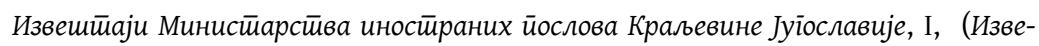

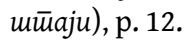

3 Брийанц̧и о Краљевини Јуїславији, ІІ (Британции), р. 13.

4 Investigation confirmed the assassins were followers of Zogu's opponent Fan Noli (Велојић 2016, p. 145-146). 
orthodox population in Shkodra were with Montenegro, due to border vicinity, so that more teachers came from those areas.

Between two world wars 'Sveti Sava' school in Shkodra was a part of clerical school autonomy, although it was dependent on state politics. The aspirations of Albanians were to affirm the newly formed state, together with Albanian orthodox church, which would take all clerical power over orthodox population in Albania. Considering the national and ethnic setting of the school, it became the focus of Yugoslav state and was monitored by the consulate in shkodra, which resulted in sending a number of teachers from Yugoslav Kingdom.

Serbian schools in Albania, particularly the one in Shkodra, were supervised by the school official from Podgorica. However, due to pressure from the Albanian government, the official was suspended. Supervision of Serbian schools in Albania was clearly regulated in 1930 by acts of Ministries of Education and Foreign Affairs:

„The Ministry of Foreign Affairs has the honour to inform that the Royal Embassy in Tirana considers that supervision of our schools in Shkodra and Vraka should be done, as until now, by the Royal Consulate in Shkodra, to which the principals of the mentioned schools are to submit reports on events, activities and achievements in these schools, particularly at the beginning and end of the school year. The Consulate in turn is to forward these reports to the Ministry of Education. Supervision by the Consulate should be carried out in a discreet way, considering special position of those schools, which completely excludes total and normal supervision, carried out by our educational authorities in our territory ${ }^{\text {“5 }}$

The letter above clearly points out the inability of normal supervision of activity in Serbian schools, even by the Consulate. The situation was particularly complicated after closing Greek schools ( 45 out of 75 in total), after complaints that Greek teachers held connections with the nationalist league Epirotes. Two Greek teachers were then convicted to 12 and 8 years in prison, under the aggravating circumstances of practising espionage and informing their Ministry of Army of Albania. ${ }^{6}$

5 Архив Југославије (АЈ), фонд 66 Министарство просвете Краљевине Југославије, ф. 7, Министарство иностраних послова Министарству просвете одељењу за основну наставу, пов. ठр. 5239 од 22. марта 1930.

6 Ibid. Посланство Краљевине Југославије у Тирани Министарству иностраних послова, политичком одељењу, пов. 1374 од 17. јула 1930. 
The ambassador in Tirana called for balance and tactfulness in view of possible closure of Serbian schools following the Greek scenario. The teacher Vuk Stojković was mentioned in this aspect, who unadvisedly let his photograph be published in the paper Vreme, even though he was an Albanian citizen. ${ }^{7}$

The case of teacher Stojković posed an additional burden to $\mathrm{Yu}$ goslav embassy in Tirana, after an anonymous letter was sent to the Minister of Education assistant. The letter accused the teacher of espionage, although he was held in high esteem by the military circles in Yugoslavia. The letter states the following:

„Indeed, he came across certain information, which he delivered to our military command and thus convinced them of his patriotism, however, he deceived our military officers by asking questions in an indirect way, and in some cases, they entrusted him with aspirations and intentions of our army. These intentions and plans were passed on to Albanian and Italian intelligence services by the teacher's wife, for which activity he was paid in gold. It is known that he already received more than 800 gold coins, which he used to build a house in Podgorica and invest in the bank under a different name, so that he would not be discovered". 8

This affair reached the Consul in Shkodra, so the teacher and his wife were promptly sent off. However, owing to military connections, especially in bordering areas, no investigation was carried out. ${ }^{9}$

Despite an incriminating spy affair, Vuk Stojković was considered a citizen of the Kingdom of Albania. Being an Albanian citizen meant only a formality, because Yugoslav educational authorities made an effort to employ only verified staff as teachers. In this way, teachers remained within Yugoslav Ministry of Education. Female teacher Vasilija Čerenković, e.g., was willing to relocate to Shkodra if she was to remain the employee of the Ministry of Education. In addition to salary received from the Ministry of Foreign Affairs, she regularly received extra teaching fees. She further demanded that her years of work as a teacher in Shkodra be entered into her pension contributions, and to get promotion in Yugoslavia. ${ }^{10}$ Besides a

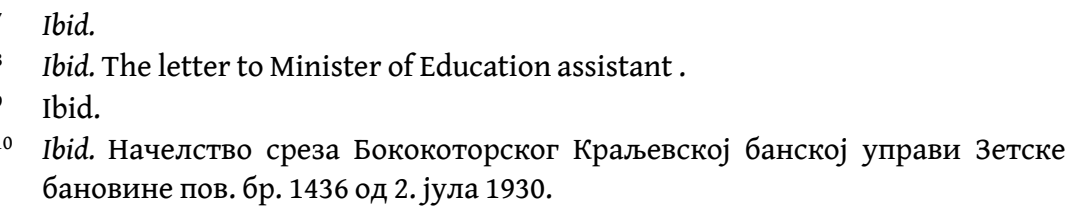


regular salary and pension contribution, this job also included a benefit of a monthly income provided by the Ministry of Foreign Affairs. It was not stated to what purpose the Ministry would pay fees to employees of other ministries without direct advantage, so this raises the question about the purpose of sending teachers from Yugoslavia to Albania and if they were meant to do other jobs apart from teaching.

The number of teachers in this school exceeded that of students. In September 1930, the school manager Haralampije Andrić claimed that 10 students attended the first grade, while there were 19 students in the second, 18 in the third and 10 in the fourth, respectively.

Accordingly, two classes were formed, therefore two teachers were enough, although there were four of them. ${ }^{11}$ Besides a small number of pupils, there were other reasons for a limited number of teachers. The status of Serbian schools in Albania from 1928 got rather delicate, making it difficult to hire new staff. Any increase in number of teachers led to suspicion of Albanian authorities, which was not in the best interest of Serbian minority. According to Yugoslav consul in Shkodra, the number of teachers was sufficient and well-qualified to ensure teaching and successful school activity. The consul himself pointed out the difficulties Serbian schools came up with after decision of Albanian authorities from 1929, stating that teaching should be done in Albanian, following the curriculum of Albanian primary schools, where Serbian would be used one lesson per day as mother tongue and two lessons of History and Geography. ${ }^{12}$

Despite conducting most teaching in Albanian, the principal and the teachers did their best to provide the best education possible in approved Serbian lessons. Books had to be procured from the territory of Yugoslav Kingdom via official channels exclusively, in order not to raise suspicion of Albanian authorities. School management used the Consulate in Shkodra to address the Embassy, and requests were forwarded to the Ministry of Foreign Affairs of the Kingdom of Yugoslavia. This Ministry in turn, sent the request to the Ministry of Education, so the books were sent to Albania, upon approval. For

11 Ibid. Извештај конзулату Краљевине Југославије у Скадру пов. бр. 7 од 10. септембра 1930.

12 Ibid. Писмо југословенског конзула у Скадру Министарству иностраних послова, политичком одељењу пов. 882 од 10. септембра 1930. 
the school year 1931/32, textbooks were shipped from Yugoslavia, as follows: ${ }^{13}$

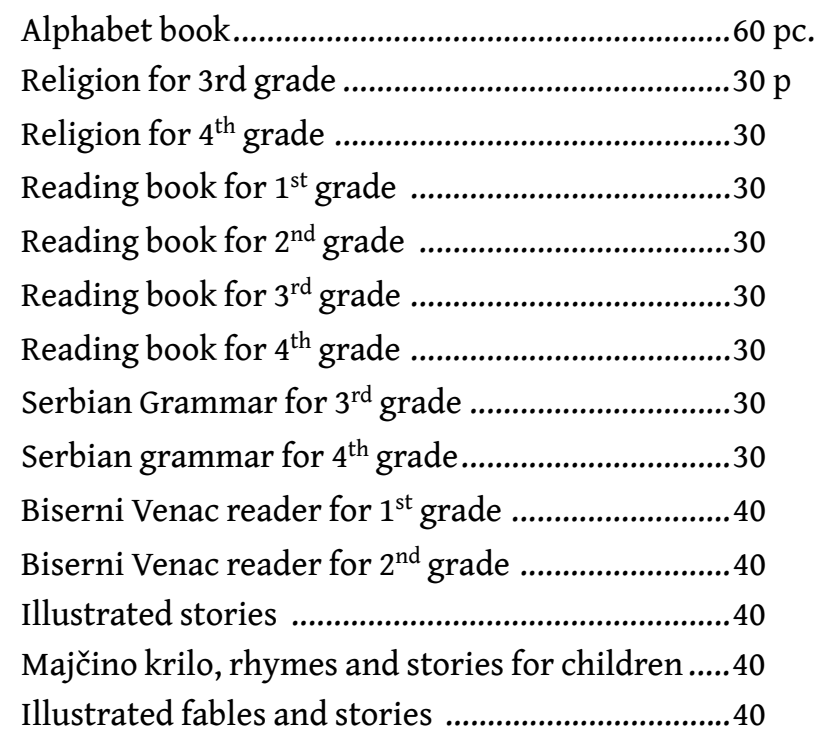

The number of pupils did not change much in the following period. The school consisted of three groups in four grades and two groups of kindergarten. The number of pupils per group can be presented in this way: ${ }^{14}$

First grade: enrolled grade: 8 boys, 6 girls, total 14

left school: - boy, 1 girl, total 1

attended grade: 8 boys, 5 girls, total 13

repeated grade: 1 boy, 1 girl, total 2

completed grade: 7 boys, 4 girls, total 11

Second grade: enrolled: 8 boys, 13 girls, total 21

left: 2 boys, 1 girl, total 3

attended: 6 boys, 12 girls, total 18

repeated: - boys, 1 girl, total 1

completed: 6 boys, 11 girls, total 17

Third grade: enrolled: 9 boys, 6 girls, total 15

left: 2 boys, 1 girl, total 3

13 Ibid, Управа школе конзулату Краљевине Југославије пов. бр. 8 од 19. августа1931.

14 Ibid, Управа основне школе у Скадру конзулату Краљевине Југославије пов. бр. 4 од 29.јуна 1931. 
attended: 7 boys, 5 girls, total 12

repeated: 1 boy, - girl, total 1

completed: 6 boys, 5 girls, total 11

Fourth grade: enrolled: 3 boys, 4 girls, total 7

left: 1 boy, - girl, total 1

attended: 2 boys, 4 girls, total 6

repeated: - boys, 1 girl, total 1

completed: 2 boys, 3 girls, total 5

Two groups of kindergarten consisted of 18 and 12 children, respectively.

The report from the following year shows that there were newcomers to the school, but also that several old pupils left, which made the number of pupils in grades 2, 3 and 4 different compared to the previous year: ${ }^{15}$

First grade: enrolled: 8 boys, 10 girls, total 18

left: 1 boy, 2 girls, total 3

repeated: 2 boys, 1 girl, total 3

completed: 5 boys, 7 girls, total 12

Second grade: enrolled: 9 boys, 5 girls, total 14

left: 1 boy, 1 girl, total 2

repeated: - boys, - girls, total -

completed: 8 boys, 4 girls, total 12

Third grade: enrolled: 8 boys, 4 girls, total 12

left: - boys, - girls, total -

repeated: 1 boy, 1 girl, total 2

completed: 7 boys, 3 girls, total 10

Fourth grade: enrolled: 8 boys, 4 girls, total 12

left: - boys, - girls, total -

repeated: - boys, - girls, total -

completed: 8 boys, 4 girls, total 12

The report did not take into account the difference in the number of pupils, therefore the reasons of leaving school were not mentioned.

15 Ibid, Извештај о раду школе преослеђен Министарству иностраних послова од 3. јула 1932. 
The attitude of Albanian government concerning Serbian schools, predicted, as quoted, compulsory education in Albanian. The Ministry of Education issued an order in 1930 that school enter pupils' names into register without the ending 'ić', which was followed by change of the school name and imposed new stamp with Albanian emblem (Димић, 1990, p. 920). Besides, there were attempts to impose Albanian teachers as well. Albanian government attempted to position their teacher, a Muslim at school, so as to get better perception of the activities carried out by the principle and staff. ${ }^{16}$ After supervisor's protest, the teacher was withdrawn, but a new one, a Catholic was employed, so the principal acting upon order of Yugoslav consulate, had to reject such a solution of staff. As explanation, insufficient number of pupils was given, and the new teacher could not form his class. Albanian education inspection put pressure on the principal, threatening strict measures for rejecting to fulfil the request of the Ministry of Education. After probable intervention of the Yugoslav embassy, the principal received the guarantee from the Head of compulsory education in Albanian Ministry of Education that a new teacher would not be accepted, due to reasons the school had already given. In the consul's opinion, the attempt of the Albanian government to remove the remaining privileges left in Serbian elementary school by hiring those teachers failed. ${ }^{17}$

However, Serbian school in Shkodra was closed for entirely different reasons. Namely, in this period relations between Italy and Albania got problematic, especially after Albanian government decided not to extend the treaty of Tirana from 1926, which led to suspension of Italian subsidies and loan payment and resulted in economic pressure on Albania. ${ }^{18}$

In order to diminish Italian influence, Albanian government decided to change Article 206 of its Constitution in 1933, which stated that teaching and education of Albanian citizens should come under exclusive authority of the state. ${ }^{19}$ As a result, private schools,

16 A year earlier a female Albanian teacher was hired, and another attempt by Albanian authorities to impose a teacher was prevented by intervening of the embassy in Tirana. Ibid, Конзулат у Скадру Краљевском посланству у Тирани пов. бр. 633 од 9. јула 1931.

17 Ibid. Југословенски конзулат у Скаадру Министарству иностраних послова, политичком одељењу пов. 903 од 18. невембра 1932.

18 Британции, II, p. 158.

19 Извештаји, IV, p. 111. 
73 in total, in Albania were closed. ${ }^{20}$ These measures were primarily aimed at closing catholic schools run by Italian Jesuits and Franciscans, so as to reduce the influence of Italian culture in general (Димић 1990, p. 921).

At the same time, Albanian Ministry of Education passed a new education law, which came into effect in October 1934. According to this law, all educational staff had to be secular and funded by the Ministry of Education. Elementary education predicted obligatory teaching for all children aged 4-13, whereas young men aged 13-18, who did not complete elementary school were to attend courses, but without learning a foreign language, in order to prevent Italian propaganda in schools. ${ }^{21}$

According to Article 167 of the law, all buildings, including schools under foreign management, were taken over and submitted to the Ministry of Education for further use, which meant that Albanian government claimed the building and land of Serbian elementary school in Shkodra. ${ }^{22}$ Besides, the law predicted acceptance of emigrant children to state boarding schools, which included children of Albanians from the territory of Yugoslavia. ${ }^{23} \mathrm{New}$ Albanian educational policy enabled founding and assistance of schools outside Albania. Schools were planned in places with predominant Albanian population to teach subjects in connection with national culture ${ }^{24}$ Such a procedure only made existence of schools on Yugoslav territory funded by Albanian government official. ${ }^{25}$ In the following years, Albanian government endeavoured to educate as many young men from Kosovo and Metohija as possible, with the intention of spreading nationalism and irredentism in Albanian youth. After return to Yugoslavia, these men were to become the most prominent agitators of annexation of Kosovo and Metohija to Albania. ${ }^{26}$ According to reports of Yugoslav military intelligence

20

21 АЈ, 66, ф. 7. Отправник послова у Тирани Министарству иностраних послова политичком одељењу пов. 1371 од 24. новембра 1934.

22 Ibid.

23 Ibid, Interpretation of education law in Serbian, 1934

24 Ibid.

25 In previous years certain districts in Kosovo and Metochia were investigated, since there was doubt of existence of Albanian schools taught by Muslim teachers and funded by Albanian government. Ibid, Краљевска банска управа Вардарске бановине начелнику среза гњиланског пов. ठр. 151 од 13.02.1930.

26 Ibid, Report on Albanian education policy from 1937. 
groups, up to 1937, over 1,000 young men from Kosovo and Metohija were educated in Albanian military schools and returned to Yugoslavia. Besides, on instructions of Albanian Embassy in Belgrade, students from Albania got in touch with students of Albanian nationality, Yugoslav citizens, in order to spread propaganda ${ }^{27}$ Thus, a strong intellectual nucleus of Albanian irredentism was created in Yugoslavia, maintaining close connections with Albania.

According to new legal norms, Serbian elementary school in Shkodra was closed, teachers were dismissed, and the pupils resumed their education in Albanian state schools. The Ministry of Foreign Affairs of Yugoslav Kingdom claimed that the advantage of stopping Italian cultural and religious influence far exceeded the damage done by closing schools (Димић 1990, p. 921).

The school in Shkodra was closed after Albanian Constitution was changed and the new education law was passed. These measures, although applying to all foreign schools in Albania, were brought with the aim to diminish Italian influence in culture and religion. Serbian school shared the destiny of 75 foreign schools that came under scrutiny of the state. However, it would be wrong to interpret closing of this school as collateral damage in Italian-Albanian conflict. Introduction of obligatory education in Albanian, imposing teachers of Albanian nationality to the school, correcting pupils' surnames for the official protocol, as well as changing the name of the school with the new stamp, were measures that Albanian government took over the years with the aim of national homogenization of Slovene population in Albania. Yugoslavia could only alleviate the consequences of such denationalization, by bringing pupils to attend schools to Yugoslavia, but this gave poor results. On the other hand, Albanian government, assisted by Italians, managed to attract a greater number of their citizens from Yugoslavia for education, after which they were sent back to find work as office clerks.

27 Ibid. Document of intelligence department of Yugoslav military authorities on plans of Albanian Ministry of Education. 


\section{UNPUBLISHED SOURCES}

Архив Југославије, фонд 66 Министарство просвете Краљевине Југославије

\section{PUBLISHED SOURCES}

Брит̄анц̧и о Краљевини Јуїославији, II, (1986), приредио Живко Аврамовски, Београд: Архив Југославије, Загреб: Глобус.

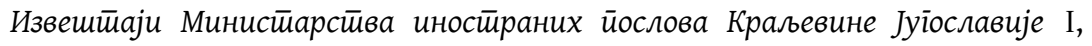
(2005), приредили Нада Петровић и Саша Илић, Београд: Архив Југославије.

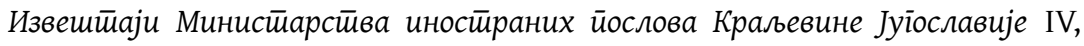
(2009), приредили Нада Петровић и Јелена Буришић, Београд: Архив Jугославије.

REFERENCES Krizman B. (1975). Vanjska politika Jugoslavenske države. Zagreb: Školska knjiga.

Аврамовски Ж. (1986). Балканска Анӣанӣа. Београд: Институт за савремену историју.

Велојић Д. (2016). Ратни планови војске Краљевине СХС/Југославије према Албанији 1928-1938. Башӣина, 41, 145-155.

Димић Љ. (1990). Школско питање и односи између Југославије и Алба-

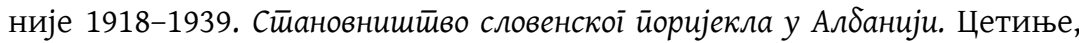
907-924.

Милак Е. (1987). Иі̄алија и Јуіославија 1931-1937. Београд: Институт за савремену историју.

Павловић С. (2001). Ист̄орија Балкана. Београд: Клио.

Протић Ф. (1914). Срӣска школа у Скаgру. Цетиње: Обод.

ДАЛИБОР 3. ВЕЛОЈИЋ

ИНСТИТУТ ЗА СРПСКУ КУЛТУРУ - ПРИШТИНА / ЛЕПОСАВИЋ

РЕЗИМЕ

УКИДАњЕ СРПСКЕ ОСНОВНЕ ШКОЛЕ У СКАДРУ 1934.

Српска основна школа у Скадру основана је 1828. године и била у надлежности црквено-школске општине. У периоду између двасветска рата школа је, иако је зависила од албанске др- 
жаве, одржавала тесну везу са југословенским конзулатом у Скадру, а преко њега и са посланством у Тирани. Југословенске власти, тачније Министарство просвете и Министарство иностраних послова, водећи рачуна о томе да се превише не умешају у албанску унутрашњу политику, настојале су да школу опреме уџбеницима на српском језику, као и да обезбеде адекватан учитељски кадар. Пре свега, водило се рачуна о задржавању српског језика у школи, пошто је албанска просветна политика предвиђала извођење већег дела наставе на албанском.

Албанска политика подржана од Италијана, имала је за циљ културну и просветну интеграцију албанског друштва. Увођење наставе на албанском језику, наметање албанских учитеља, као и промена имена школе, резултати су такве политике националне хомогенизације.

Школа је укинута коначно 1934. године након измене албанског устава и доношења новог просветног закона. Да би сузбила италијански утицај, албанска влада одлучила је да настава и васпитање албанских грађана пређе искључиво у надлежност државе. Само укидање иницирали су албанско-италијански конфликти, услед којих су све стране школе на територији Албаније укинуте, њихове зграде предате министарству просвете на коришћење, а просветни персонал отпуштен и замењен албанским. Југословенска држава могла је једино да ублажи последице ове денационализације довођењем ученика на школовање у Југославију, али је то дало слабе резултате.

КључнЕ РЕчи: Српска основна школа у Скадру, Албанија, Краљевина Југославија, просветна политика.

Овај чланак је објављен и дистрибуира се под лиценцом Creative Commons Ауторство-Некомерцијално Међународна 4.0 (CC BY-NC 4.0 | https://creativecommons.org/licenses/by-nc/4.0/).

This paper is published and distributed under the terms and conditions of the Creative Commons Attribution-NonCommercial International 4.0 licence (CC BY-NC 4.0 | https://creativecommons.org/licenses/by-nc/4.0/). 